Secretary General, Sudan Pastoralists Union, Khartoum, Sudan. C/O P.O. Box 204, Khartoum North, Sudan.

\title{
A FIELD SURVEY OF SOME CAMEL (CAMELUS DROMEDARIUS) PRODUCTION TRAITS AND CONSTRAINTS IN BUTANA AREA, SUDAN
}

(With Six Tables and One Figure)

By

\section{A.E.M. DAROSA and H. AGAB*}

* Associate Professor, College of Vet. Med. and Animal Production, Sudan Univ. of Science and Technology, P O Box 204, Khartoum North, Sudan. (Received at 12/12/2007)

$$
\begin{aligned}
& \text { مسح حقلي حول بعض ميزات ومعوقات إنتاج الإبل } \\
& \text { بمنطقة البطانة بالسودان } \\
& \text { آدم الحاج موسى ، حامد عقب محمد }
\end{aligned}
$$

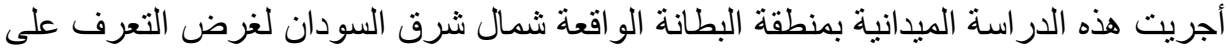

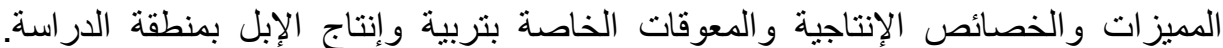

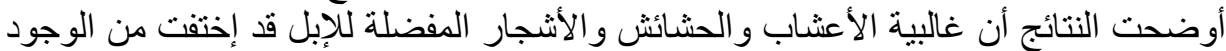

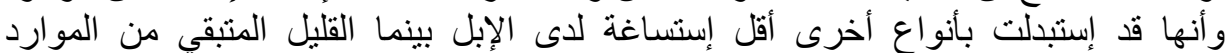

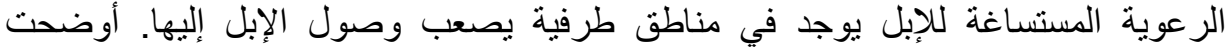

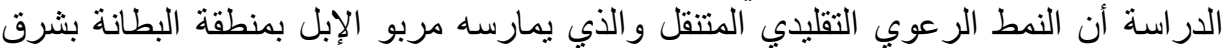

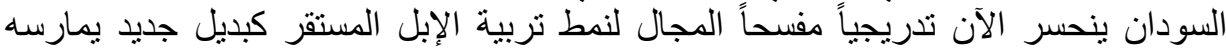

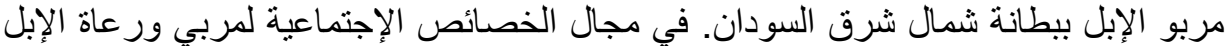

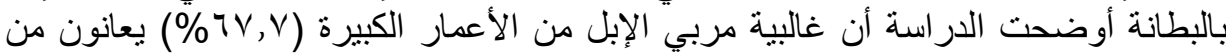

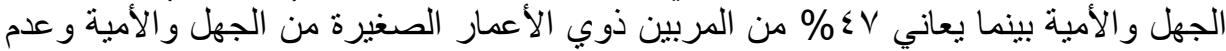

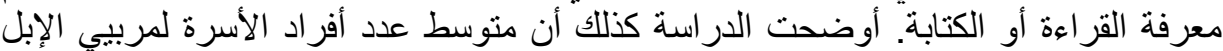

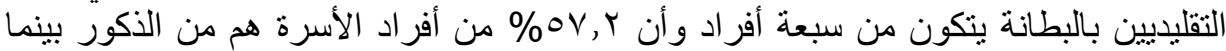

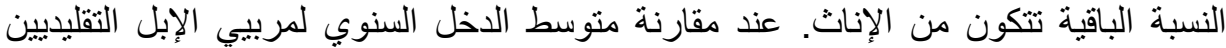

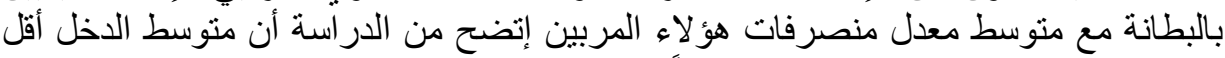

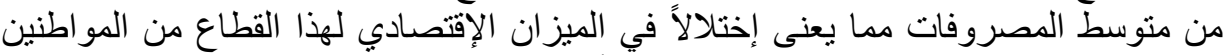

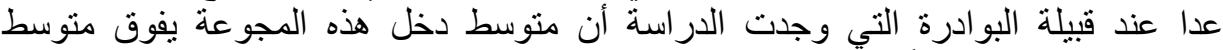

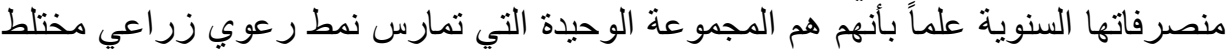

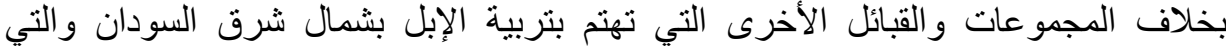

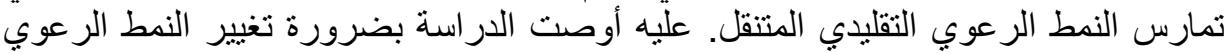

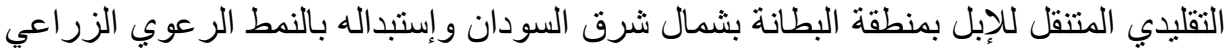

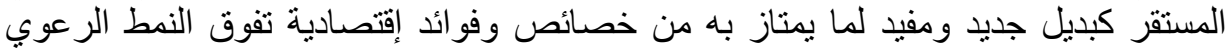

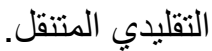




\section{SUMMARY}

This field survey was conducted in Butana area, northeastern Sudan, to study the dromedary camel production features, traits and constraints in the study area. The study revealed that most of the camel palatable and preferred forage plants and trees had disappeared and were replaced by non-palatable forage plants whereas the few remaining camel preferred forage plants were now restricted only to remote inaccessible areas. The study also showed that the classical mode of nomadism among camel herders in Butana area was sharply declining, giving way to settlement as a new emerging mode of camel husbandry. Regarding the level of education among camel herders in Butana region, it was found that majority $(67.7 \%)$ of older herders were illiterate while it was $47.8 \%$ of the younger ages were illiterate. The average size of the camel herder's families was found to be composed of seven persons with $57.2 \%$ of the family members was males while the remaining percentage $(42.8 \%)$ was females. When the mean total annual income of the camel herding tribes was compared with the mean total annual expenditure, it was found that the income was lower than the expenditure for all the tribes except for the Bawadra group which was the only group practicing agropastoralism among all other camel keeping tribes in Butana area. Therefore, the study proposed that agropastoralism characterized by sedentary production system based on land ownership should be encouraged as the most suitable and profitable alternative available for the traditional camel nomads in Butana area of Sudan.

Key words: Camel production, husbandry, forage plants, Sudan.

\section{INTRODUCTION}

Camels are the most capable animal species in utilizing marginal areas and in survival and production under harsh environmental conditions (Knoess, 1977; Gauthier-Pilters and Dagg, 1981; Hjort and Hussein, 1986; Abbas and Tilley, 1990; Schwartz, 1992). Many pastoral groups and communities in diverse eco-zones throughout the world are depending on camels for their livelihood. This dependence consists of utilization of camel meat, milk, leather and wool, exportation of live camels, uses as an important sport and tourism resource in the Arabian Gulf countries and, lastly, the use of camels as animals for packing, transport and riding (Wilson, 1984; Abdurahman and Bornstein, 1991; Kohler-Rollefson, 1992; Snow et al., 1992). 
In eastern Sudan, camels (Camelus dromedarius) are raised mainly in Butana region and Red Sea coast. In the former, the camel population was estimated to be around 750.000 head representing about $25 \%$ of total Sudan camel herd population (Darosa, 2005). The main camel keeping tribes in Butana region are the Lahawiyin, Kawahla, Shukriya, Rashaida, Bija and Bawadra.

Camel research in the Sudan has been focused mainly on functional anatomy, diseases and reproduction. Research on husbandry and management systems, feeding and nutrition and production performance are scanty (Majid, 2000; Majid, 2006). In the last few years some new modes of camel husbandry practices were developed for the improvement of the traditional systems of camel keeping methods. This paper presents data on the current status of nomadism among dromedary herders in Butana region, the forage plants and trees preferred by camels and it details some aspects of the socioeconomics of pastoral camel husbandry in the region, particularly regarding sources of income and total income and expenditure among dromedary herders in Butana area. Moreover, the study presents information concerning the indigenous knowledge and practices of camel herders in the study area.

\section{MATERIALS and METHODS}

Description of the study area: Butana plain is a semiarid clay region covers most of the present Kassala and Gedaref States in Eastern Sudan. It lies between Latitude $13^{\circ} 40^{\prime}$ and $17 \AA^{\circ} 50^{\prime}$ North and Longitude $32^{\circ}$ $40^{\prime}$ and $36^{\circ} 00^{\prime}$ East. It is bound by the Main River Nile on its northwestern border, the Blue Nile on its southwestern edge, the Atbara River in the northeast and by the railway connecting Kassala and Sennar on the south (Fig. 1). The area is composed of mountainous ranges intersecting the plain to the western and southern borders. It is crossed by many seasonal rivers namely, Atbara, Seitite, Ba-Salam, Gash and Rahad Rivers. Small temporary seasonal valleys do run through these plains during the rainy season. The rocky basement complex forms the geological underlining of Butana plains with sandy and stony soils in the north, light non-cracking clay in the Central, Eastern and Western regions and dark cracking clay in the South. As a result of this and with the exception of small water catchments in the mountains mentioned before, very limited water resources are available. Seasonal shallow surface water wells are present as well as few very deep bore wells. However, the amount of water and the persistence of reserves during the 
summer dry season depend on the quantity of rainfall during the wet season. In the Butana, a tropical continental climate prevails ranging from a sub-equatorial condition with rain in the south to desert climate in the north. Most of the rains are in the form of showers or thunderstorms. The rainfall in Butana region is highly variable from one year to the other. It ranges between $600 \mathrm{~mm} /$ year in the southeast to less than 100 $\mathrm{mm} /$ year in the northwest. As always in the semiarid regions, rainfall is the most important climatic factor in Butana because people and their livestock depend on this factor which supports the growth of the vegetation for their animals. The annual mean temperature ranges from $32{ }^{\circ} \mathrm{C}$ during the day to $16 \circ \mathrm{C}$ at night in January (winter) and from $46^{\circ}$ $\mathrm{C}$ during the day to $27^{\circ} \mathrm{C}$ at night in May-June (summer). Two vegetation zones are existing in the area, namely semi-desert Acacia shrub and short grasslands of the North Central Sudan and secondly, the low woodland savannah of Central Sudan. The vegetation of Butana is constantly changing as a result of annual rainfall, accidental fire outbreaks and expansion of agriculture and grazing (Saint-Martin et al., 1992).

The Butana area is inhabited by transhumant camel owning tribes in its northern part while in its southern part is populated by agropastoralists who practice mainly mechanized rain-fed agricultural activities for production of sorghum and sesame grains besides considerable livestock raising activities. However, irrigated agricultural schemes also exist in the northern and south-western borders of the study area comprising the New-Halfa and Rahad Agricultural Schemes. These schemes were mainly established as government efforts aimed towards encouraging settlement of the transhumant livestock nomads inhabiting Butana region as well as diversifying the activities of these pastoralist people towards agropastoralism (Abbas et al., 1992; SaintMartin et al., 1992).

\section{Methods of data collection}

To achieve the objectives of the study a comprehensive questionnaire was designed and implemented covering all aspects of study parameters. The questionnaire was based on a model previously tested in Saudi Arabia, Niger and Butana area of Sudan (Abbas et al., 1992). However, little modification was made to suit the conditions, local situations and requirements of the present study. The study aspects included in the questionnaire comprised of camel herd preferred forage plants and trees, socioeconomic aspects of camel husbandry, status of 
nomadism among pastoral camel herders and, finally, indigenous knowledge and practices of camel pastoralists in the region. Throughout the study period which was conducted in the rainy season of the years 2001, 2002 and 2003, the herders and households of 209 camel herds belonging to the major camel keeping tribes in Butana region were interviewed. Small amounts of animal medicines were provided as incentive to cooperative herders.

All adequately completed questionnaire forms were statistically processed and analyzed using the suitable and appropriate statistical programmes.

\section{RESULTS}

The different types of forage plants preferred by camels in the Butana area are presented in Table 1. These included trees, legumes, grasses, bushes and shrubs known to grow in the study area. The most preferred forage plants were rarely found while several new nonpalatable forage plants were frequently encountered in central Butana.

The current situation of nomadism among camel herders in Butana area is sharply declining, when compared to the situation during the last two decades, giving way to settlement as a new emerging mode of camel husbandry as shown in Table 2 .

Regarding the level of education among camel herders in Butana region, it was found that $67.7 \%$ of older herders (above 30 years old) were illiterate while $47.8 \%$ of the younger ages ( $15-30$ years old) were illiterate (Table 3 ). The average size of the camel herder's families was found to be composed of seven persons with $57.2 \%$ of the family members was males while the remaining percentage $(42.8 \%)$ was females.

When the mean total annual income of the camel herding tribes was compared with the mean total annual expenditure, it was found that the income was lower than the expenditure for all the tribes except for the Bawadra group (Table 4). However, the percent dependence of different camel herding tribes in Butana region on camel management as a main source of income in contrast to other sources is shown in Table 5. Some information regarding the traditional concepts and indigenous knowledge and practices of camel herders in Butana area is presented in Table 6 . 
Table 1: Camel preferred forage plants and trees in Butana region.

\begin{tabular}{|c|l|c|}
\hline Type of forage & \multicolumn{1}{|c|}{ Scientific name } & Local name \\
\hline \multirow{5}{*}{ Trees } & Acacia seyal & Sunut \\
& Acacia tortilis & Samar \\
& Acacia melifera & Kitir \\
& Acacia radiana & Sayyal \\
& Acacia chrenbergiana & Salam \\
& Acacia nubica & Lao'at \\
& Ziziphus spinachristi & Sidir \\
\hline \multirow{5}{*}{ Bushes } & Capparis decidna & Tondub \\
& Cadapa rotunolifolia & Kormut \\
\hline \multirow{5}{*}{ Legumes } & Ipomoea cordofana & Tabar \\
& Ipomoea cardiocephala & Hantout \\
& Tripulus terrestris & Diraisa \\
& Indigofera hochestetteri & Shara \\
& Chorchorus olitorius & Siha \\
& Blepharis edulus & Siha \\
\hline \multirow{5}{*}{ Grasses } & Aristida adesensionis & Dobalab \\
& Panicum turgidum & Tumam \\
& Arestida mutablis & Ghabash \\
\hline
\end{tabular}

Table 2: Status of nomadism among camel herders in Butana region.

\begin{tabular}{|l|c|c|c|}
\hline \multirow{2}{*}{ Status of families } & \multicolumn{3}{|c|}{ Year } \\
\cline { 2 - 4 } & 1984 & 1994 & 2003 \\
\hline Nomadic families & $153(73.3 \%)$ & $69(33.0 \%)$ & $46(22.0 \%)$ \\
Semi-nomadic families & $21(10.0 \%)$ & $103(49.3 \%)$ & $73(34.9 \%)$ \\
Settled families & $35(16.7 \%)$ & $37(17.7 \%)$ & $90(43.1 \%)$ \\
\hline
\end{tabular}

Table 3: Age and level of education of camel herders in Butana region.

\begin{tabular}{|l|c|c|c|c|c|c|}
\hline $\begin{array}{c}\text { Age group } \\
\text { (years) }\end{array}$ & $\begin{array}{c}\text { No. of } \\
\text { herders }\end{array}$ & \multirow{2}{*}{$\%$} & \multicolumn{4}{|c|}{ Level of education (\%) } \\
\cline { 4 - 7 } & & & Illiterate & Khalwa* & $\begin{array}{l}\text { Primary } \\
\text { education }\end{array}$ & $\begin{array}{l}\text { Secondary } \\
\text { education }\end{array}$ \\
\hline $15-30$ & 23 & 11.0 & 47.8 & 4.3 & 43.5 & 4.3 \\
$31-49$ & 93 & 44.5 & 67.7 & 12.9 & 15.1 & 4.3 \\
Above 50 & 93 & 44.5 & 67.7 & 17.2 & 10.8 & 4.3 \\
Total & 209 & 100 & & & & \\
\hline
\end{tabular}

* Khalwa is a classical Quranic (religious) school for young children in Sudan. 
Table 4: Mean total annual income and expenditure of camel herders in Butana region.

\begin{tabular}{|l|l|l|l|}
\hline \multirow{2}{*}{ Tribe } & \multicolumn{2}{|c|}{ Economic variables } & \multirow{2}{*}{\begin{tabular}{c} 
Total \\
\cline { 2 - 3 }
\end{tabular}} \\
\cline { 2 - 3 } & $\begin{array}{l}\text { Mean total income } \\
\text { (Sudanese pounds*) }\end{array}$ & $\begin{array}{c}\text { Mean total expenditure } \\
\text { (Sudanese pounds*) }\end{array}$ & (Sudanese pounds*) \\
\hline Kawahla & $5448947(28.8 \%)$ & $13444921(71.2 \%)$ & $18893868(100 \%)$ \\
Bawadra & $26955722(55.0 \%)$ & $24302917(45.0 \%)$ & $53958639(100 \%)$ \\
Rashaida & $7280000(31.0 \%)$ & $16198171(69.0 \%)$ & $23478171(100 \%)$ \\
Bija & $2655909(20.1 \%)$ & $10569590(79.9 \%)$ & $13225499(100 \%)$ \\
Doweihiyin & $5217551(34.2 \%)$ & $10044816(65.8 \%)$ & $15262367(100 \%)$ \\
Lahawiyin & $6946552(43.5 \%)$ & $9028621(56.5 \%)$ & $15975173(100 \%)$ \\
Total & $57204681(40.6 \%)$ & $83589036(59.4 \%)$ & $140793717(100 \%)$ \\
\hline
\end{tabular}

* Exchange rate during study period: 1 USD $=2245$ Sudanese pounds.

Table 5: Sources of income for different camel herding tribes in Butana.

\begin{tabular}{|l|c|l|}
\hline \multicolumn{1}{|c|}{ Tribe } & $\begin{array}{c}\text { Dependence on } \\
\text { camel rearing (\%) }\end{array}$ & \multicolumn{1}{c|}{ Other sources of income (\%) } \\
\hline Kawahla & 98.9 & 1.1 (Agriculture + small animal herding) \\
Bawadra & 32.8 & 67.2 (agriculture) \\
Bija & 98.8 & 1.2 (Agriculture) \\
Doweihiyin & 85.9 & 14.1 (Agriculture + sheep herding) \\
Rashaida & 95.3 & $4.7 \%$ (Trade + small animal herding) \\
Lahawiyin & 73.4 & 26.6 (Agriculture + small animal herding) \\
\hline
\end{tabular}

Table 6: Indigenous knowledge and practices of camel herders in Butana area.

\begin{tabular}{|l|l|l|}
\hline & Type of practice & Period \\
\hline 1 & Age of puberty & $3-4$ years for females and $5-7$ years for males. \\
2 & Duration of coitus & 15 minutes. \\
3 & $\begin{array}{l}\text { Least period needed for traditional } \\
\text { detection of pregnancy }\end{array}$ & $15-25$ days after successful mating. \\
4 & Gestation period & $12-13$ months. \\
5 & $\begin{array}{l}\text { Period allowed for calf suckling to } \\
\text { stimulate dam milk let-down }\end{array}$ & $1-2$ minutes. \\
6 & Watering interval & $3-4$ days in the summer, $5-9$ days in the winter. \\
\hline
\end{tabular}




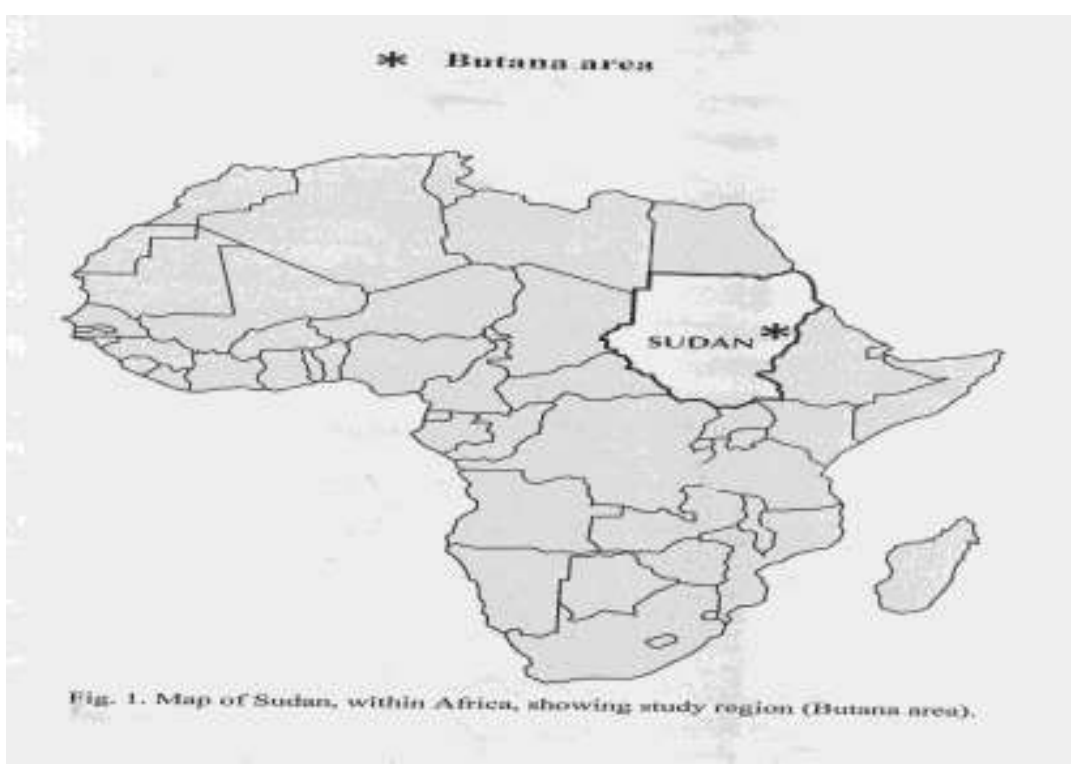

DISCUSSION

The disappearance of most of the palatable and preferred grazing plants in Butana region as agreed by the local Range and Pasture Conservation Authorities in both Kassala and Gedaref States as well as the continuous encroachment of mechanized crop production agricultural activities accompanied by removal of considerable plant and vegetation cover in the natural camel range habitat, constitute real disturbing practices and form important environmental and ecological threat. The most camel preferred plants, such as Blepharis edulus and Chorchorus olitorius, are now restricted only to remote inaccessible areas, natural depressions and courses of seasonal valleys and water run-ways.

This study revealed the presence of drastic impacts that disturbed the long standing stability of the nomadic pastoral communities in Butana. That disturbance was manifested in the rapid fall down of nomadism throughout the period from the year 1984 through 1994 to 2003 at declining percentages of $73.3 \%, 33.0 \%$ to $22.0 \%$, respectively. This decline was accompanied by increase in the percentages of camel herders practicing semi-nomadic production system from 10\% through $49.3 \%$ to $34.9 \%$ while the settled camel herders changed in percentage from $16.7 \%$ through $17.7 \%$ to $43.1 \%$, respectively, for the same period. The establishment of the New Halfa and Rahad Mechanized Agricultural Schemes in the natural range land of Butana during the 1960's and 1970 's besides the very severe and historical drought that hit Sudan and 
many neighbouring African countries during the 1983-1984 had aggravated the situation and forced many camel herders to start settling since these periods (Darosa, 2005).

The percentage of male and female ratio in camel herders' family members recorded in this study where $57.2 \%$ and $42.8 \%$, respectively which were close to the results of Majid and Sakr (1998) who reported a percentage as $60 \%$ versus $40 \%$ in the same area of study. The high percentage ( $71 \%$ ) of the best age range (30 - 39 years old) among camel herders in Butana might be a good signal that still camels are currently, and may be in the near future, managed by reliable, medium-age and powerful herders. However, the domination of illiteracy among camel herders needs immediate correction, particularly among the young and medium-aged nomads as it is hoped that education would, definitely, improve husbandry and management skills of the herders.

The deficit between expenditure and income recorded in all camel-keeping tribes in Butana, except the Bawadra, is a good indicator that the traditional and pure nomadic mode of camel husbandry practice has to be shifted to agro-pastoralism in order to utilize the crop byproducts for camel feeding and to avoid the other drawbacks and limitations of the classical migratory system of camel husbandry in Butana region.

A considerable percentage of camel nomads in Butana appreciated the services provided by the mid-wives and mobile government health centres in the Butana plains (57\% - 96.6\%). However, the classical religious schools (known locally as Khalwas) were well recognized and considered by most of the camel herders in Butana.

Camel herders in Butana showed their interest and acceptance to any form or policy of financial assistance and/or bank loans that can be used to diversify and improve their business with fewer obligations towards selling their camels to meet family expenses.

Despite all the above mentioned constraints and despite the fact that $94.7 \%$ of camel pastoralists in Butana area have inherited this practice from their ancestors, a considerable proportion among these nomads $(97.1 \%)$ is still interested to keep practicing this profession. The main reasons for this willing were to satisfy the social prestige given to camel owners, to keep existing the traditional heritage of camel herding which continued over 2500 years ago (Majid and Sakr, 1998) and to satisfy the household needs for food, milk, meat and other camel products. 
This study also confirmed the high degree of self-dependence as well as the huge and wealthy knowledge of camel herders in Butana area on different aspects of camel management, particularly the traditional indigenous and ethno-medical practices which are common features among camel pastoralists in other dromedary keeping communities (Schwartz and Dioli, 1992; Jasra and Isani, 2000; Kohler-Rollefson et al., 2001).

Out of this extensive field study, several conclusions could be drawn. However, the following are just a few:

1- The traditional camel migratory pastoral system of production is decreasing and the rapid diminishing of cost/benefit nomadic system has forced some camel owners to get rid of this style of life.

2- Drought attacks in coincidence with extensive encroachment of mechanized crop farming activities into natural camel grazing areas lead to shortage of forage and water resulting into delayed production and reproduction output, increased mortality rates and consequently decreased camel population.

3- The continuous selling of camels to meet the needs of production cost is an other stressing factor on camel production activities.

4- The agropastoralism characterized by sedentary production system based on land ownership was proved as the most suitable and profitable alternative available for the traditional camel nomads.

\section{REFERENCES}

Abbas, B. and Tilley, P. (1990): Pastoral management for protecting ecological balance in Halaib District, Red Sea Province, Sudan. Nomadic Peoples. 29: 77-86.

Abbas, B.; Chabeuf, N.; Saint-Martin, G.; Bonnet, P.; Maillaird, A.; Beshir, H. and Musa, B.E. (1992): Camel pastoralism in the Butana and north eastern Sudan: an interdisciplinary study. Nomadic Peoples. 31: 64-84.

Abdurahman, O.A.Sh. and Bornstein, S. (1991): Diseases of camels (Camelus dromedarius) in Somalia and prospects for better health. Nomadic Peoples. 29: 104-112.

Darosa, A.E.M. (2005): Studies on Some Camel Production Traits and Health in Butana Area, Sudan. Ph.D. Thesis. University of Khartoum, Sudan. P. 135. 
Gauthier-Pilters, H. and Dagg, A.I. (1981): The camel: it's evolution, ecology, behaviour and relationship to man. Chicago Univ. Press. USA.

Hjort, A. and Hussein, M.A. (1986): Camel herd dynamics in southern Somalia: Long term development and milk production implications. Camel Forum. 18: 1-28.

Jasra, A.W. and Isani, G.B. (2000): Socio-economics of camel herders in Pakistan. The Camel Applied Research and Development Network (CARDN). Pakistan/ACSAD/P94/2000.

Knoess, K.H. (1977): The camel as a meat and milk animal. World Animal Review. 22: 39-44.

Kohler-Rollefson, I. (1992): The Raika dromedary breeders of Rajasthan: A pastoral system in crisis. Nomadic Peoples. 30: 74-83.

Kohler-Rollefson, I.; Mundy, P. and Mathias, E. (2001): (eds.). A Field Manual of Camel Diseases. London, U.K.; Intermediate Technology Group Publishing. pp. 254.

Majid, A.A. (2000): The one-humped camel (Camelus dromedarius) in the Sudan. Annotated Bibliography (1905-2000). National Centre for Research, Sudan. pp. 123.

Majid, A.A. (2006): Camel Research in the Sudan. Annotated Bibliography: 1905-2000. National Centre for Research, Sudan. pp. 240.

Majid, A.M. and Sakr, I. (1998): The socioeconomics of camel herding in Eastern Sudan. CARDN/ACSAD Camel/ P39/ 1998.

Saint-Martin, G.; Delmet, C.; Zubeir, A.R.Y.; Peyre, de Fabriques, B.; Harbi, M.S.M.A. and Bagadi, H.O. (1992): Camel Project of Butana: Final Report. Maison Alfort, France, IEMVT. pp. 128.

Schwartz, H.J. (1992): Productive performance and productivity of dromedaries (Camleus dromedarius). Animal Research and Development. 35: 86-98.

Schwartz, H.J. and Dioli, M. (eds.) (1992): The One-humped Camel (Camelus dromedarius) in Eastern Africa: A pictorial guide to diseases, health care and management. Verlag Josef Margraf, Weikersheim, Germany.

Snow, D.H.; Billah, A.M.; Ridha, A. and Frigg, M. (1992): Plasma concentrations of some vitamins in camels. Proc. First Int. Camel Conf. Dubai, U. A. E. Pp. 335-338.

Wilson, R.T. (1984): The Camel. Longman Group Ltd. Essex, U.K. 
Assiut Vet. Med. J. Vol. 54 No. 116 January 2008 